\title{
CHINESE FIR (CUNNINGHAMIA LANCEOLATA) A GREEN GOLD OF CHINA WITH CONTINUES DECLINE IN ITS PRODUCTIVITY OVER THE SUCCESSIVE ROTATIONS: A REVIEW
}

\author{
FAROOQ, T. H. ${ }^{1,2,3}-$ YAN, W. ${ }^{3}-$ RASHID, M. H. U. ${ }^{1,2}-$ TIGABU, M. ${ }^{4}-$ GILANI, M.M. ${ }^{1,2}-$ ZOU, X. \\ H. ${ }^{1,2}-$ WU, P.F. ${ }^{1,2^{*}}$ \\ ${ }^{I}$ Forestry College, Fujian Agriculture and Forestry University, Fuzhou, 350002 Fujian \\ Province, PR China \\ ${ }^{2}$ Fujian Provincial Colleges and University Engineering Research Center of Plantation \\ Sustainable Management, Fuzhou, 350002 Fujian Province, PR China \\ ${ }^{3}$ National Engineering Laboratory for Applied Technology of Forestry and Ecology in South \\ China, Central South University of Forestry and Technology, Changsha, 410000 Hunan \\ Province, PR China \\ ${ }^{4}$ Southern Swedish Forest Research Center, Faculty of Forest Science, Swedish University of \\ Agricultural Sciences, PO Box 49, SE-230 53 Alnarp, Sweden \\ *Corresponding author \\ e-mail: fjwupengfei@126.com, fjwupengfei@fafu.edu.cn; phone/fax: + 86-591-8378-0261
}

(Received $1^{\text {st }}$ Apr 2019; accepted $19^{\text {th }}$ Jun 2019)

\begin{abstract}
Chinese fir (Cunninghamia lanceolata) is a prized timber species, which is grown in China from more than a thousand years. According to $8^{\text {th }}$ national forest inventory data, Chinese fir plantations area expanded over an area of 11 million hectares, which occupies almost $18.2 \%$ area of all plantations in China principally in southern China. Successive rotations with clear cutting have become a common practice for Chinese fir plantations. These management practices on continues bases have led to a declining in yield production. Therefore, a serious concern has been raised on the Chinese fir plantations less yield and long-term productivity decline, particularly about the current rotation regime. In this review, we discussed the general causes of Chinese fir productivity decline and their effective solution. In forest conservation, the decline in soil quality is a serious ecological problem and recalcitrant litter, monoculture planting has aggravated the mechanism of soil degradation in Chinese fir plantations. The deteriorated soil properties in Chinese fir plantations were well mirrored in the reduction of plantation growth. Traditional plantation method of successive rotation without the period of fallow and management system of clear cutting, complete ploughing, burning of site and residues removal could be blamed for site degradation resulting in the poor growth and productivity decline of Chinese fir plantations. Complete burning and clear-cutting can lead to soil degradation by the loss of nutrients and organic matter. Therefore, a comprehensive knowledge of Chinese fir in terms of low productivity causes and solutions will allow us better forest management strategies and better development of plantation and afforestation throughout China.
\end{abstract}

Keywords: productivity, soil quality, soil degradation, forest conservation, Chinese fir, China

\section{Introduction}

Plantation forests are the significant part of the forest ecosystems of China (Fig. 1), and Chinese fir (Cunninghamia lanceolata (Lamb) Hook) is one of most planted species in these plantation forests. It is a typical evergreen sub-tropical conifer with high timber yield, excellent timber quality, and fast growth. It is the third most commonly planted species in plantation forests worldwide (State Forestry Administration, 2010). Chinese fir is often used in the provision of the ecosystem as well as inorganic matter storage. It 
is characterized by its fast growth rate when grown in a monoculture plantation, producing volumes of up to $450 \mathrm{~m}^{3} / \mathrm{ha}$ after 25 years (Wang et al., 2014). Its timber accounts for 24\% of China's national commercial timber production (FAO, 2007). Fast growing species, along with the quick economic returns also provide the opportunity to mitigate the climate change by sucking the big carbon emissions, which had a significant impact on global climate (Yang et al., 2005). Since 1949, due to afforestation policies area under Chinese fir plantations increased nearly tripled (Li et al., 2013).

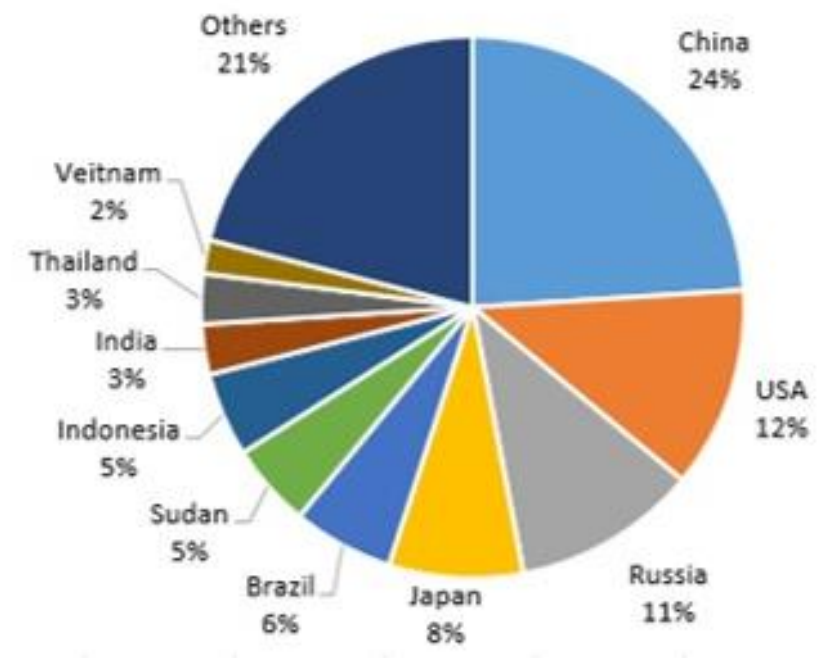

Figure 1. Distribution of plantations forests worldwide (FAO, 2007)

As one of the most important subtropical coniferous species, Chinese fir plantations have been using across China for more than one thousand years, especially in southern China (Wu, 1984). China gradually increased its area under plantations since the 1970s (Yu, 1997) and southern China have the highest percentage (54.3\%) of forests primarily the plantations (Wang et al., 2014). According to $8^{\text {th }}$ national forest inventory, data indicates that Chinese fir plantations expand over an area of 11 million hectares which occupies almost 18.2\% area of all plantations in China and 6\% worldwide (FAO, 2015; State Forestry Administration, 2014).

Since the 1980s, the cultivated area under Chinese fir plantations has been expanded from disconnected patches to large plantations (hills to high mountains) to meet the growing need (Ma et al., 2002). Majority of the Chinese fir plantations are monoculture and increasing timber demand resulted in shorter rotations (15 years) without the period of fallow (Bi et al., 2007; Tian et al., 2011). Successive rotations with clear cutting have become a common practice (Hu et al., 2014; Ma et al., 2007). These management practices on continues bases have led to declining in yield production along with soil degradation due to below-ground resources loss (nutrient loss) and accumulation of toxic substances (Chen et al., 2013; Hu et al., 2014). Shorter rotations have led to a high nutrient loss in foliage and biomass per tree component decreased as compare to longer rotations especially in the branches per unit biomass (Fang, 1987; Ma et al., 2007; Zhou et al., 2015). Therefore, a serious concern has been raised on the Chinese fir plantations less yield and long-term productivity decline (Bi et al., 2007; Zhao et al., 2013), particularly about the current rotation regime. Therefore, we have reviewed various aspects of Chinese fir related to short rotations regime, which are directly involved in 
Chinese fir productivity decline like nutrient availability, nutrient cycling, soil microbes and their biochemical activities etc. We try to uncover the basic problems in the Chinese fir decline over successive rotations and possible effective solutions provided by the various previous studies. This study would provide a reference for future researches.

\section{Chinese fir description}

The genus "Cunninghamia" is an evergreen coniferous specie in the cypress family Cupressaceae. Traditionally, it is said that this genus contains two species, Chinese fir (Cunninghamia lanceolata Lamb) Hook) and Taiwan fir (Cunninghamia konishii), but genetic obedience suggested them as the same species which is usually known as "Chinese fir".

They are native to China, Taiwan, Northern Vietnam, and Laos. Distribution of Chinese fir in China is shown in (Fig. 2). They may reach a height of $50 \mathrm{~m}$, generally with the conical shape with tiered and horizontal branches, which often somewhat pendulous toward the tips. Chinese fir has green needle-like leaves, which are softly spun, leathery and stiff (Fig. 3). Needles spiral around the stem in an upward arch. Chinese Fir is a valued species in China which is vital because of its fast growth and high-quality timber wood (i.e., straight and decay resistant), along with its historical value and significant culture it is used as an ornamental tree.

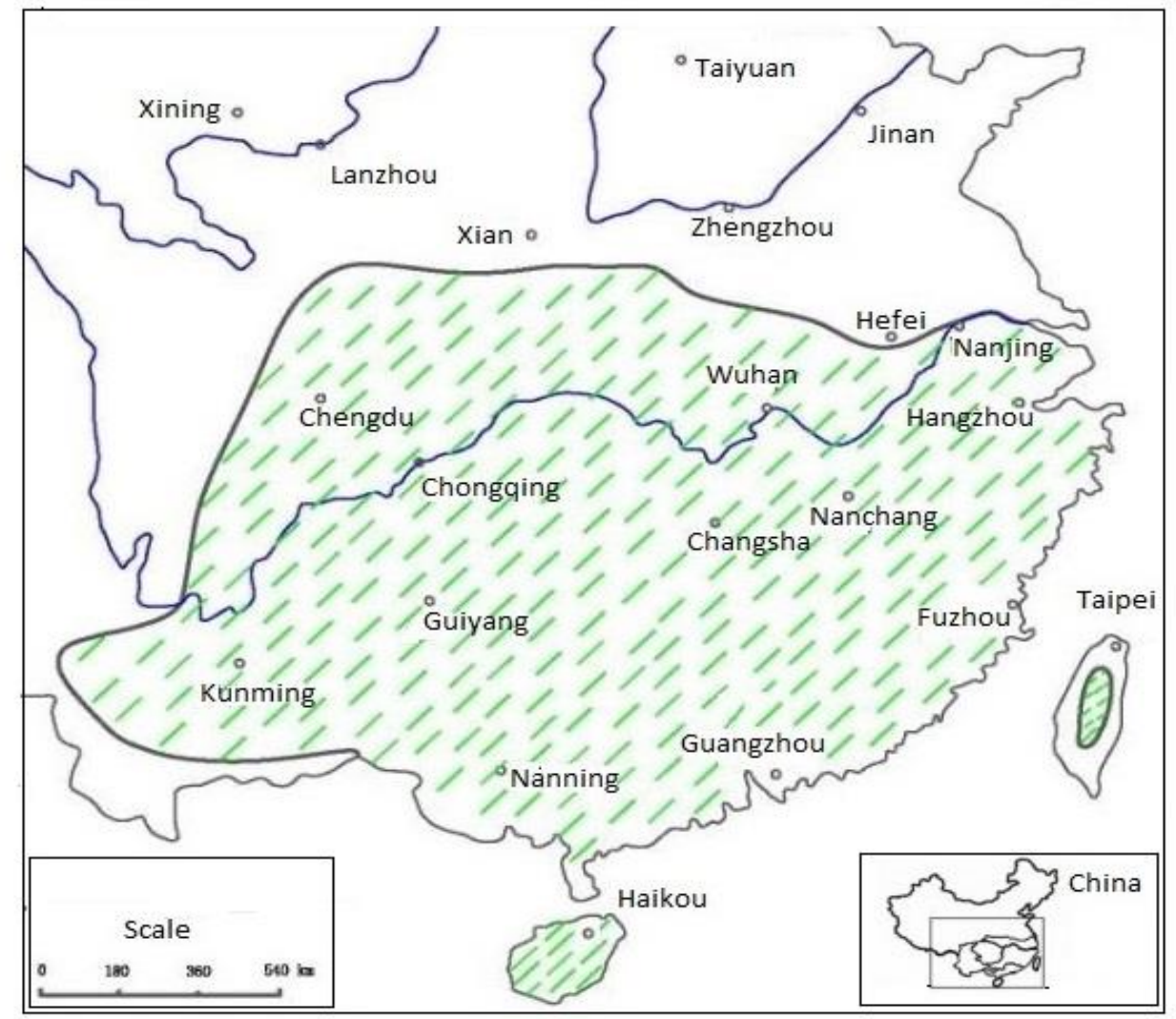

Figure 2. Distribution of Chinese fir (Cunninghamia lanceolata) in China mainly spread in southern China (Wang et al., 2012) 


\section{-11058 -}

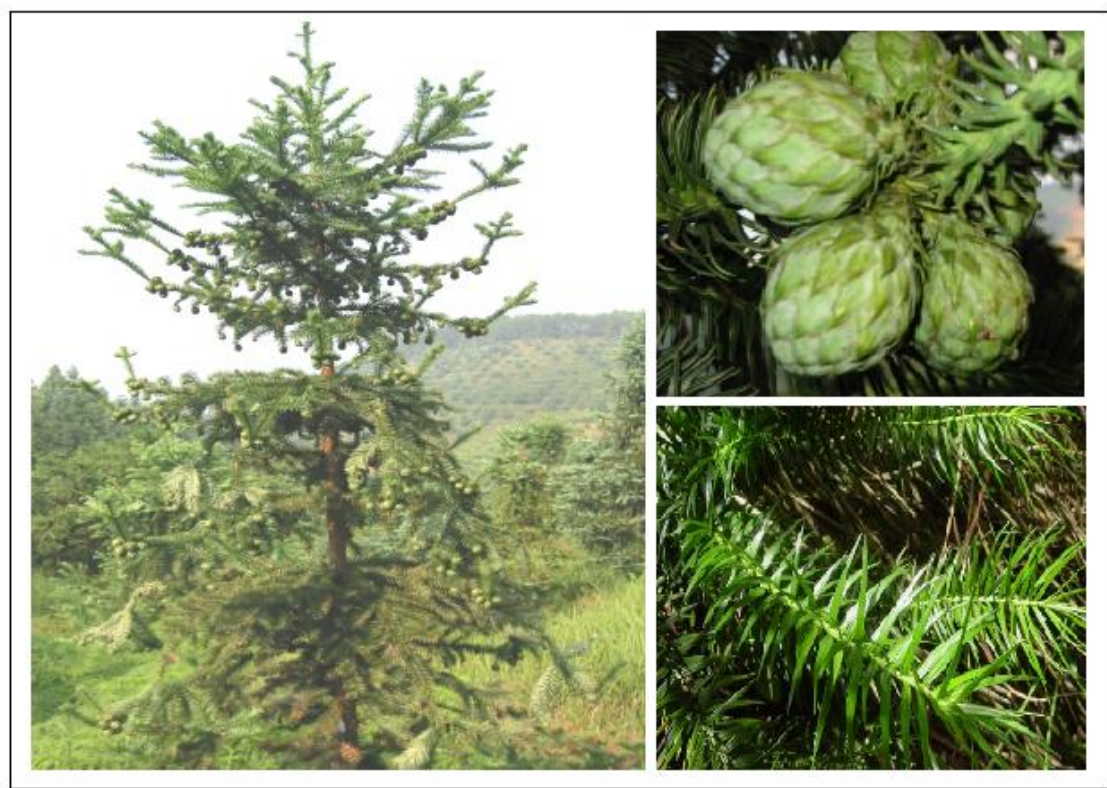

Figure 3. Description of Chinese fir (Cunninghamia lanceolata (Lamb) Hook) tree

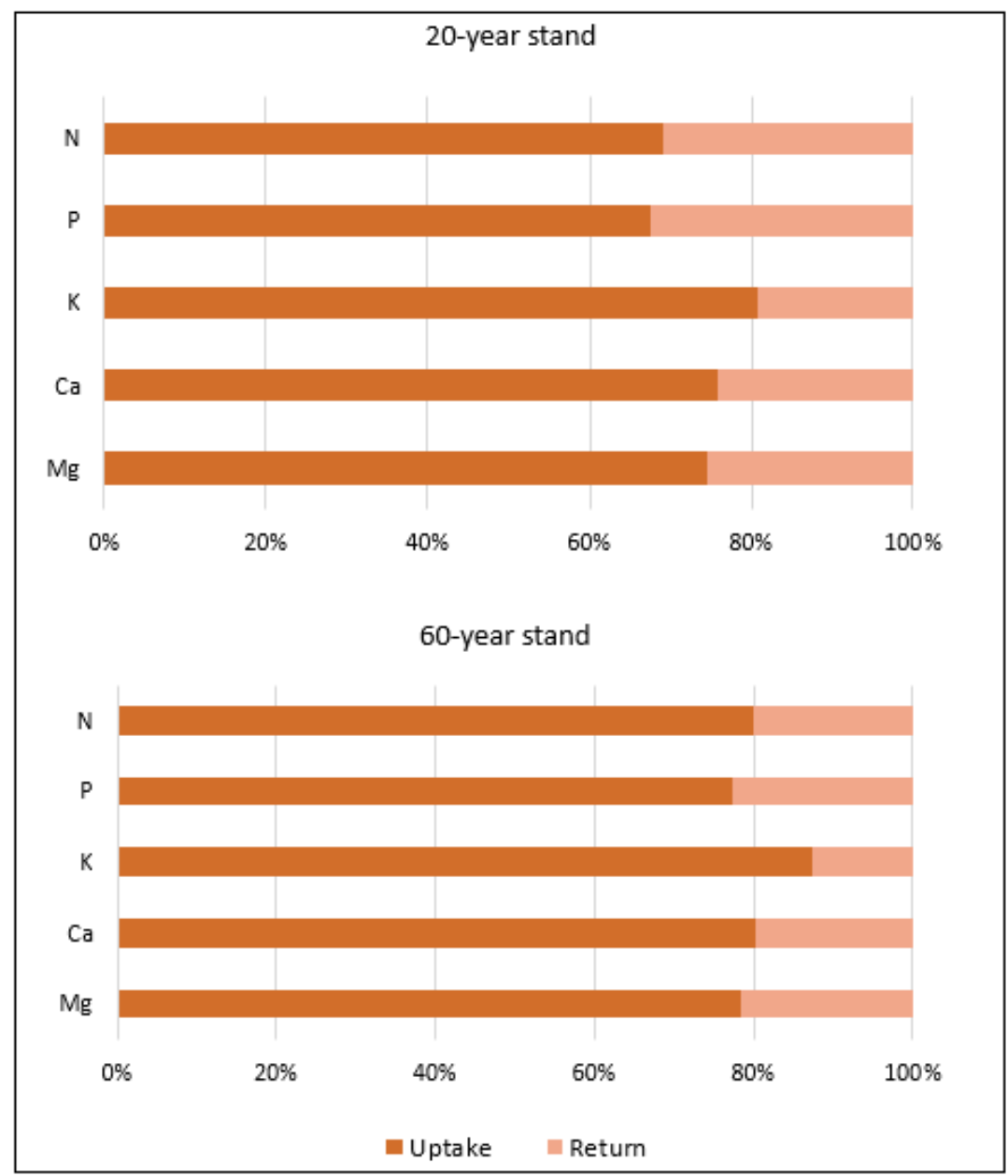

Figure 4. Nutrient uptake, return and uptake/return ratio Chinese fir plantations of different ages $\left(\mathrm{kg}_{\mathrm{hm}} \mathrm{hm}^{-2} \mathrm{a}^{-1}\right)$ 
Stand development can be the key factors in the nutrient distribution and cycling as well as in biomass production (Li, 1996; Ma et al., 2002, 2007; Zhao et al., 2013). Different factors influence the nutrient absorption of the trees, which include growth rate, nutrient use efficiency and stand nutrient demand (Hobbie, 2015). Climatic as well as physical and chemical factors also affect the nutrient contents and nutrient use efficiency (Piao et al., 2010). According to Ma et al. (2007), annual nutrient uptake and nutrient use efficiency in Chinese fir plantations increased while the nutrient return decreased with stand development. Soil microbes are also the key ingredients in maintaining good soil structure by gas exchange and good drainage, which keeps soil healthy (Bhardwaj et al., 2014).

Data in the Table 1 showed fungal population firstly increased from 1-year-old plantation to 20-year-old plantation but decreased in 40-year-old plantations. Bacterial population decreased from 1-year-old plantation to 20 -year-old but again increase from 20 -year-old to the 40-year-old plantation. Overall, microbial population decreased in 20 -year-old plantation due to the decrease in bacterial population.

Table 1. Soil microbial population in different aged Chinese fir (Cunninghamia lanceolata) plantations $\left(10^{3} \cdot g^{-1}\right.$ soil)

\begin{tabular}{c|c|c|c}
\hline \multirow{2}{*}{ Soil microbes } & \multicolumn{3}{|c}{ Plantation age } \\
\cline { 2 - 4 } & $\mathbf{1 ~ y r .}$ & $\mathbf{2 0}$ yr. & $\mathbf{4 0} \mathbf{y r}$. \\
\hline Fungi & 74 & 468 & 199 \\
Bacteria & 16900 & 13660 & 15760 \\
Total microbes & 16974 & 14218 & 15959 \\
\hline
\end{tabular}

\section{Nutrient contents and biochemical activity of soil microbes}

Chinese fir plantations consume a large number of nutrients because of its fast growth (Farooq et al., 2019a), and due to short rotation periods, nutrient contents availability decreased significantly over the successive rotations. In Chinese fir plantations, soil nutrient contents decreased drastically as the rotation increased (Fang, 1987; Chen et al., 1990). Data in Table 2 showed that soil humus carbon (SHC) was $37.6 \mathrm{gkg}^{-1}, 33.8 \mathrm{gkg}^{-1}$, and $32.4 \mathrm{gkg}^{-1}$ in first, second and third rotation respectively during Chinese fir plantation. Soil total nitrogen (TN) was $4.28 \mathrm{gkg}^{-1}, 3.91 \mathrm{gkg}^{-1}$ and $3.36 \mathrm{gkg}^{-1}$ in first, second and third rotation respectively while total phosphorous (TP) was $0.27 \mathrm{gkg}^{-1}, 0.23 \mathrm{gkg}^{-1}$ and $0.14 \mathrm{gkg}^{-1}$. In first rotation soil total Potassium (TK) was $19.7 \mathrm{gkg}^{-1}$, moreover, in the second and third rotation, it was $16.5 \mathrm{gkg}^{-1}$ and $14.3 \mathrm{gkg}^{-1}$ (Table 2). SHC decreased up to $15.7 \%$ in the second rotation while TN, TP, and TK decreased up to $18.4 \%, 9.6 \%$, and $2.4 \%$, respectively.

In terms of third rotation, SHC decreased up to $32 \%$ from the first to third rotation while the TN, TP, and TK decreased up to $36 \%, 61.2 \%$, and $11.4 \%$, respectively. As the soil depth got deeper, the contents of all the elements declined over successive rotations (Zhang et al., 2004). Plant available contents also decreased from first to the third rotation. When the Chinese fir plantation was regenerated from the site of first rotation, available nitrogen $\left(\mathrm{N}_{\mathrm{A}}\right)$, available phosphorous $\left(\mathrm{P}_{\mathrm{A}}\right)$ and available potassium $\left(\mathrm{K}_{\mathrm{A}}\right)$ decreased significantly by $42.4 \%, 44.1 \%$, and $37.5 \%$ respectively while on the site of second rotation, $\mathrm{N}_{\mathrm{A}}, \mathrm{P}_{\mathrm{A}}$ and $\mathrm{K}_{\mathrm{A}}$ decreased by $24.2 \%$, and $47.8 \%$ and $5.9 \%$ (Table 2). When the plantations start getting mature (18-20 years), the nutrient content availability 
in the soil surface layer $(0-20 \mathrm{~cm})$ was only $50.8 \%, 14.1 \%$ and $36.6 \%$ for $\mathrm{N}, \mathrm{P}$ and $\mathrm{K}$, respectively. In the $20-40 \mathrm{~cm}$ and $40-60 \mathrm{~cm}$ soil layers' nutrient contents also decreased markedly. Due to the low rate of litter-fall decomposition, this cause imbalance between nutrient uptake and return (Liao et al., 2000). During a study in south China, Yang et al. (2005) described that in surface soil layer $(0-20 \mathrm{~cm})$ hydrolysable nitrogen content declined in the second and third rotations by $3 \%$ and $18 \%$, respectively, as compared to first rotation while available phosphorus decreased $7 \%$ and $20 \%$ under Chinese fir stands.

Soil nutrients decline over the successive rotations could be reflected in soil microbial population and in their biochemical activities (Bhardwaj et al., 2014). In Chinese fir plantations, when continuous cropping took place over successive rotations biochemical activity of soil microbes decline significantly (Chen et al., 2015; Wu et al., 2017). Nitrogen fixation was $13.2 \%$ in the first rotation while it decreased up to $11.4 \%$ and $5.9 \%$ in second and third rotation respectively. Ammonification also declined by $82 \%$, ranging from $1.6 \mathrm{mg} \mathrm{N} . \mathrm{g}^{-1}$ soil to $0.4 \mathrm{mg} \mathrm{N}^{-1}$ soil from first to third rotation. Fiber decomposition was $3.3 \mathrm{CO}_{2} \mathrm{mg}$. $\mathrm{g}^{-1}$ soil, $0.8 \mathrm{CO}_{2} \mathrm{mg}$. $\mathrm{g}^{-1}$ soil and $1.4 \mathrm{CO}_{2} \mathrm{mg} \mathrm{g}^{-1}$ soil in the first, second and third rotation while respiration was $1.6 \%, 1.1 \%$, and $0.8 \%$ respectively. Nitrogen fixation, fiber decomposition, and respiration decreased by $54.1 \%, 59.2 \%$, and $39.8 \%$ when continuous cropping of Chinese fir plantation took place for twice (Table 3).

Table 2. Variation in the soil total nutrient contents, available nutrient contents, soil microbe's biochemical activity, and productivity over the successive rotations in Cunninghamia lanceolata plantations

\begin{tabular}{c|c|c|c}
\hline Nutrient contents & $\mathbf{1}^{\text {st }}$ rotation & $\mathbf{2}^{\text {nd }}$ rotation & $\mathbf{3}^{\text {rd }}$ rotation \\
\hline Total nitrogen $\left(\mathrm{gkg}^{-1}\right)$ & 4.28 & 3.91 & 3.36 \\
Total phosphorus $\left(\mathrm{gkg}^{-1}\right)$ & 0.271 & 0.238 & 0.14 \\
Total potassium $\left(\mathrm{gkg}^{-1}\right)$ & 19.7 & 16.5 & 14.3 \\
Humus carbon $\left(\mathrm{gkg}^{-1}\right)$ & 37.6 & 33.8 & 32.4 \\
Hydrolysable nitrogen $\left(\mathrm{mgkg}^{-1}\right)$ & 105.3 & 95.3 & 73.2 \\
Available phosphorus $\left(\mathrm{mgkg}^{-1}\right)$ & 58.7 & 52.3 & 28.7 \\
Available potassium $\left(\mathrm{mgkg}^{-1}\right)$ & 101.5 & 59.6 & 53.2 \\
\hline
\end{tabular}

Table 3. Variation in the biochemical activity of soil microbes over the successive rotations in Cunninghamia lanceolata plantations

\begin{tabular}{c|c|c|c}
\hline Biochemical activity & $\mathbf{1}^{\text {st }}$ rotation & $\mathbf{2}^{\text {nd }}$ rotation & $\mathbf{3}^{\text {rd }}$ rotation \\
\hline Nitrogen fixation (\%) & 13.2 & 11.4 & 5.9 \\
Ammonification $\left(\mathrm{mg} \mathrm{N.} \mathrm{g^{-1 }}\right.$ soil) & 1.6 & 0.9 & 0.4 \\
Fiber decomposition $\left(\mathrm{CO}_{2}{\mathrm{mg} . \mathrm{g}^{-1}}^{\text {soil }}\right)$ & 3.3 & 0.8 & 1.4 \\
Respiration $(\%)$ & 1.6 & 1.1 & 0.8 \\
\hline
\end{tabular}

\section{Chinese fir growth and productivity}

Chinese fir growth and production decreased over the successive rotations (Selvaraj et al., 2017). In productive Chinese fir stands (25-year-old), $280 \mathrm{t} \mathrm{ha}^{-1}$ biomass was reported with about $80 \%$ of total biomass allocated to the tree stem, which decreased 
over the successive rotations (Zhao and Zhou, 2005). The high soil nutrition consumption due to continuous cropping cause a negative impact on the tree growth of Chinese fir plantations. A decline reported in annual increment in diameter at breast height (DBH) (Farooq et al. (2019b), height and volume in Chinese fir plantations of the same age but with different rotations (Zhou et al., 2016a). Diameter at breast height $(\mathrm{DBH})$ decreased from $14.1 \mathrm{~cm}$ to $11.5 \mathrm{~cm}$ from first to third rotation (Tang et al., 2016). Plant height also decreased from $15.5 \mathrm{~m}$ to $10.8 \mathrm{~m}$ from first to the third rotation. Tree volume was $378.5 \mathrm{~m}^{3} \cdot \mathrm{hm}^{-2}, 268.8 \mathrm{~m}^{3} \cdot \mathrm{hm}^{-2}$ and $176.4 \mathrm{~m}^{3} \cdot \mathrm{hm}^{-2}$ respectively in first, second and third rotation (Table 4). The average height, DBH, and volume declined by $14.2 \%, 12.1 \%$, and $32.3 \%$, respectively in the second rotation and $22.8 \%, 36.5 \%$ and $53.2 \%$, respectively for the third rotation. Higher tree mortality reported in third rotation as compared to the first and second rotation. It was $11.2 \%, 17.5 \%$, and $21.6 \%$ respectively in the first, second and third rotation (Fig. 5).

Table 4. Variation in the growth and productivity over the successive rotations in Cunninghamia lanceolata plantations

\begin{tabular}{c|c|c|c}
\hline Growth and productivity & $\mathbf{1}^{\text {st }}$ rotation & $\mathbf{2}^{\text {nd }}$ rotation & $\mathbf{3}^{\text {rd }}$ rotation \\
\hline DBH $(\mathrm{cm})$ & 14.1 & 12.8 & 11.5 \\
Height $(\mathrm{m})$ & 15.4 & 13.6 & 10.8 \\
Volume $\left(\mathrm{m}^{3} \cdot \mathrm{hm}^{-2}\right)$ & 378.5 & 268.8 & 176.4 \\
Tree mortality $(\%)$ & 11.2 & 17.5 & 21.6 \\
\hline
\end{tabular}

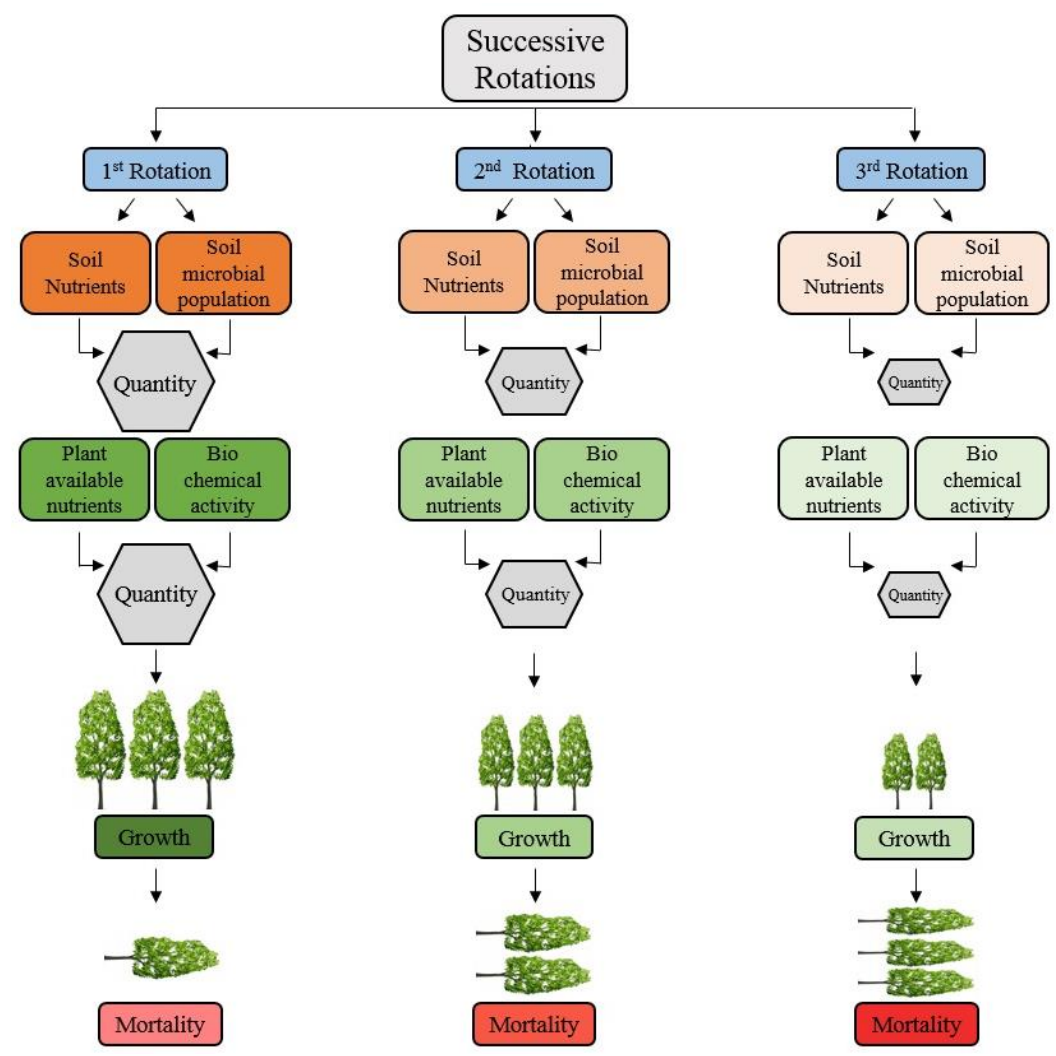

Figure 5. Graphical summary of soil quality decline affecting the Chinese fir plantations growth and productivity over the successive rotations. (Decrease in the shade of colours of boxes shows decrease in nutrients availability, biochemical activity and growth) 


\section{Discussion}

Due to its soft and adorable timber, Chinese fir is an important species of China, which is in use for manufacturing of buildings, temples, furniture, and coffins, as well as an ornamental tree. Additionally, it also used as biomass energy and pulp production (Ma et al., 2002a, b; Wood et al., 2009). Nutrient cycling and biomass production are the important components of forest productivity (Tian et al., 2011; Farooq et al., 2018) which can vary with stand age, development and different silvicultural techniques (Hou et al., 2009; Zhao et al., 2013). Chinese fir productivity decreased over the years, and current management practices and short rotation policy are highly criticized for being a reason for less productivity (Chen et al., 2004). In Chinese fir plantations, these characteristics have been described in various previous studies in different regions of China (Li, 1996; Liao et al., 2000; Chen et al., 2004; Zhang et al., 2004; Zhao and Zhou, 2005; Ma et al., 2007; Wu et al., 2011; Chen et al., 2013; Zhao et al., 2013; Tang et al., 2016; Zhou et al., 2016b; Selvaraj et al., 2017). From the last one thousand years' traditional plantation method and management system of clear-cutting, complete ploughing, burning of the site and residues removal are under-used which is blamed for site degradation resulting in the poor growth and less production of Chinese fir plantations (Zhou et al., 2016c). Complete burning is the cause of organic matter and some nutrient loss; furthermore, minerals are lost due to rainfall (Wenhua, 2004; You et al., 2015). Soil erosion increased significantly due to complete ploughing while clear cutting resulted in soil and water loss (Dias et al., 2015). Conventional management practice effects tree morphology and biomass production. Morphological characteristics such as survival rate, average diameter at breast height, average height and biomass production were lower in stands where plantations were established with clear cutting and complete burning irrespective of rotation time (Bhardwaj et al., 2014).

Monoculture plantations are also the reason for productivity decline as monoculture system has low resistance and more suspected to pest attack due to the less biodiversity and bad stability (Liu et al., 2018). Non-development of understory vegetation and no proper thinning are the critical issues in the less productivity and poor growth because understory vegetation can markedly improve the soil nutrient and enhanced the biochemical activity (Chen et al., 2004; Zhou et al., 2016b). The decline in productivity is also associated with the non-use of fertilizers as in this era fertilizers are vital for crop development especially in the rotations without a period of fellows (Havlin et al., 2016). However, some experiments by different research teams in different areas showed contradictory results regarding the benefits of fertilizers. In a research on the 5-year old plantation, Li et al. (1991) reported that fertilizer applications of $\mathrm{P}$ and $\mathrm{K}$ could increase stand growth while Liao et al. (2000) found that P application increased stand growth only at the beginning while $\mathrm{N}$ fertilizers showed no effect moreover $\mathrm{K}$ fertilizer effects negatively.

The conventional Chinese fir plantation management system has to be replaced with the recently science based and rational management system, which is multi-culturing, includes clear cutting but of small area and mild site preparation. Cutting leftovers should be buried rather than burned. Pure plantation should be avoided and gradually replaced with agroforestry (Chinese fir mixed plantation) such as planting different herbs and shrubs. This could enforce higher productivity with the increase of the timber production and improve the soil physical and chemical properties to certain degrees as herbs and shrubs are easy to decompose and are rich in nutrients. Hence, it will enrich the soil resources. In nutrient-poor soils, direct approach of nutrient inputting should be 
used by applying fertilizers especially the compound fertilizer containing $\mathrm{P}$ can have a huge impact on plant growth especially in south china where the sites are mostly Pdeficient.

In plantation ecosystem soil microbes are the important decomposers, they are the good indicator of the soil quality and habitat change because they play an important role in nutrient transformations (Chen et al., 2015; Wu et al., 2017). Soil contains a different type of bacteria, algae, fungi, and earthworms. The optimum amount of soil microbial population increases the efficiency of fertilizer and irrigation application (Paul, 2014). Furthermore, it releases essential nutrients N, P, K, and hydrogen back to the soil. On the other hand, excessive soil organic matter can be a problem also as it encourages the growth of unwanted herbs and shrubs, moreover, it also decreases the efficiency of irrigation and fertilizer application (Brevik et al., 2015). These are some of the benefits and disadvantages that soil microbial population can provide to plantation ecosystem (Jacobsen et al., 2014). For soil microbial benefits, an optimum environment that favours soil microbial growth is necessary to build a healthy soil microbial population. Organic based fertilizers can be an excellent way to provide them a healthy environment in which they can thrive in (Hartmann et al., 2015; Hudson, 2015). General causes of productivity decline in Chinese fir plantations and their effective solutions are described in Table 5.

Table 5. Reasons of Chinese fir productivity decline and effective solutions

\begin{tabular}{|c|c|c|}
\hline $\begin{array}{c}\text { General causes of less } \\
\text { productivity }\end{array}$ & Effective solutions & References \\
\hline $\begin{array}{c}\text { Traditional plantation method and } \\
\text { management system that creates } \\
\text { site degradation }\end{array}$ & $\begin{array}{l}\text { Replacing conventional Chinese fir } \\
\text { plantation management system with } \\
\text { recently science based multicultural } \\
\text { and rational management system }\end{array}$ & $\begin{array}{l}\text { Minghe and Ritchie, 1999; } \\
\text { Hu et al., } 2006\end{array}$ \\
\hline $\begin{array}{l}\text { Short rotation pattern and } \\
\text { establishing a plantation on } \\
\text { infertile lands }\end{array}$ & $\begin{array}{l}\text { Rotation lengths should be increased } \\
\text { and plantation establishment on } \\
\text { infertile lands should be discouraged }\end{array}$ & $\begin{array}{l}\text { Ma et al., 2000a; Ma et al. } \\
\text { 2007; Slevaraj et al. } 2017\end{array}$ \\
\hline $\begin{array}{l}\text { Decline in soil fertility due to slash } \\
\text { burning and residual removal }\end{array}$ & $\begin{array}{c}\text { Avoid the activities that soil } \\
\text { compromise soil fertility. Cutting } \\
\text { leftovers should be buried rather than } \\
\text { burned }\end{array}$ & $\begin{array}{l}\text { Xiong, 2008; Ma et al., } \\
\text { 2000b; Zhijun et al. } 2018\end{array}$ \\
\hline $\begin{array}{l}\text { Clearcutting and } \\
\text { before the planta }\end{array}$ & $\begin{array}{c}\text { Clear cutting but of small area and } \\
\text { mild site perpetration }\end{array}$ & $\begin{array}{l}\text { Farooq et al., 2019a; Ma et } \\
\text { al., } 2002\end{array}$ \\
\hline $\begin{array}{l}\text { Introduction of monoculture } \\
\text { Chinese fir plantations }\end{array}$ & $\begin{array}{c}\text { Introduction of mixture plantation like } \\
\text { agroforestry system should be } \\
\text { encouraged and monoculture should } \\
\text { be discouraged }\end{array}$ & $\begin{array}{l}\text { Hu et al., 2006; Xiong, 2008; } \\
\text { Wang et al., 2008; You et al., } \\
2015\end{array}$ \\
\hline $\begin{array}{c}\text { Even aged plantations, non- } \\
\text { development of understory } \\
\text { vegetation and no proper thinning }\end{array}$ & $\begin{array}{l}\text { Introduction of multi-layering and } \\
\text { multi-aged plantations }\end{array}$ & $\begin{array}{l}\text { Lin et al., 2001; Ma et al., } \\
\text { 2002; Chen, 2007; Zhou et } \\
\text { al., 2015 }\end{array}$ \\
\hline $\begin{array}{c}\text { The decline in the soil microbial } \\
\text { population and biochemical } \\
\text { activities of soil microbes over the } \\
\text { successive rotations }\end{array}$ & $\begin{array}{c}\text { Organic based fertilizers can be an } \\
\text { excellent way to provide soil microbes } \\
\text { a healthy environment in which they } \\
\text { can thrive in }\end{array}$ & $\begin{array}{c}\text { Wang et al., 2008; Zhang et } \\
\text { al., } 2017\end{array}$ \\
\hline $\begin{array}{c}\text { Non-use of fertilizers and organic } \\
\text { manure }\end{array}$ & $\begin{array}{c}\begin{array}{c}\text { Essential use of compost and } \\
\text { fertilizers }\end{array} \\
\end{array}$ & $\begin{array}{c}\text { Chen et al., 1990; Liao et al., } \\
2000\end{array}$ \\
\hline
\end{tabular}


Acknowledgments. This study was financially supported by the National Natural Science Foundation of China (31600502 and 31870614), the Science and Technology Major Project of Fujian Province, China (2018NZ0001-1) and the Special Technology Innovation Foundation of Fujian Agriculture and Forestry University (CXZX2016059).

Conflict of interests. The authors declare no conflict of interests exists.

\section{REFERENCES}

[1] Bhardwaj, D., Ansari, M. W., Sahoo, R. K., Tuteja, N. (2014): Biofertilizers function as key player in sustainable agriculture by improving soil fertility, plant tolerance and crop productivity. - Microbial Cell Factories 13(1). DOI: 10.1186/1475-2859-13-66.

[2] Bi, J., Blanco, J. A., Seely, B., Kimmins, J. P., Ding, Y., Welham, C. (2007): Yield decline in Chinese-fir plantations: a simulation investigation with implications for model complexity. - Canadian Journal of Forest Research 37(9): 1615-1630.

[3] Brevik, E. C., Cerdà, A., Mataix-Solera, J., Pereg, L., Quinton, J. N., Six, J., Van Oost, K. (2015): The interdisciplinary nature of soil. - Soil 1(1): 117-129.

[4] Chen, C., Zhang, J., Zhou, C., Zheng, H. (1990): Researches on improving the quality of forest land and the productivity of artificial Cunninghamia lanceolata stands. - Chinese Journal of Applied Ecology 1(2): 97-106 (in Chinese with English abstract).

[5] Chen, L., Wang, S., Chen, C. (2004): Degradation mechanism of Chinese fir plantation. Chinese Journal of Applied Ecology 15(10): 1953-1957 (in Chinese with English abstract).

[6] Chen, L. (2007): Management model of multi-storied Chinese fir plantation. Subtropical Agriculture Research 3(2): 87-90 (in Chinese with English abstract).

[7] Chen, G. S., Yang, Z. J., Gao, R., Xie, J. S., Guo, J. F., Huang, Z. Q., Yang, Y. S. (2013): Carbon storage in a chronosequence of Chinese fir plantations in southern China. - Forest Ecology and Management 300: 68-76.

[8] Chen, X. L., Wang, D., Chen, X., Wang, J., Diao, J. J., Zhang, J. Y., Guan, Q. W. (2015): Soil microbial functional diversity and biomass as affected by different thinning intensities in a Chinese fir plantation. - Applied Soil Ecology 92: 35-44.

[9] Dias, T., Dukes, A., Antunes, P. M. (2015): Accounting for soil biotic effects on soil health and crop productivity in the design of crop rotations. - Journal of the Science of Food and Agriculture 95(3): 447-454.

[10] Fang, Q. (1987): Effect of replanted Chinese fir plantation on soil fertility and its growth. - Scientia Silvae Sinicae 23(4): 389-397 (in Chinese with English abstract).

[11] FAO (2007): State of the World's Forests. - Food and Agriculture Organization of the United Nations, Rome, pp. 88-90.

[12] FAO (2015): Global Forest Resources Assessment. - FAO, Rome. http://www.fao.org/forestresources-assessment/en/ (accessed on 20 December 2018).

[13] Farooq, T. H., Tigabu, M., Ma, X., Zou, X., Liu, A., Odén, P. C., Wu, P. (2018): Nutrient uptake, allocation and biochemical changes in two Chinese fir cuttings under heterogeneous phosphorus supply. - iForest-Biogeosciences and Forestry 11(3): 411-417.

[14] Farooq, T. H., Ma, X., Rashid, M. H. U., Wu, W., Xu, J., Tarin, M. W. K., He, Z., Wu, P. (2019a): Impact of stand density on soil quality in Chinese fir (Cunninghamia lanceolata) monoculture. - Applied Ecology and Environmental Research 17(2): 3553-3566.

[15] Farooq, T. H., Wu, W., Tigabu, M., Ma, X., He, Z., Rashid, M. H. U., Gilani, M. M., Wu, P. (2019b): Growth, Biomass Production and Root Development of Chinese fir in Relation to Initial Planting Density. - Forests 10(3): 236.

[16] Hartmann, M., Frey, B., Mayer, J., Mäder, P., Widmer, F. (2015): Distinct soil microbial diversity under long-term organic and conventional farming. - The ISME Journal 9(5): 1177. 
[17] Havlin, J. L., Tisdale, S. L., Nelson, W. L., Beaton, J. D. (2016): Soil Fertility and Fertilizers. - Pearson Education, India.

[18] Hobbie, S. E. (2015): Plant species effects on nutrient cycling: revisiting litter feedbacks. - Trends in Ecology and Evolution 30(6): 357-363.

[19] Hu, Y. L., Wang, S. L., Zeng, D. H. (2006): Effects of single Chinese fir and mixed leaf litters on soil chemical, microbial properties and soil enzyme activities. - Plant and Soil 282: 379-386.

[20] Hu, Z., He, Z., Huang, Z., Fan, S., Yu, Z., Wang, M., Zhuo, X., Fang, C. (2014): Effects of harvest residue management on soil carbon and nitrogen processes in a Chinese fir plantation. - Forest Ecology and Management 326: 163-170.

[21] Hudson, N. (2015): Soil Conservation: Fully Revised and Updated. - New India Publishing Agency, Delhi.

[22] Jacobsen, C. S., Hjelmsø, M. H. (2014): Agricultural soils, pesticides and microbial diversity. - Current Opinion in Biotechnology 27: 15-20.

[23] Li, Y. Q., Xu, Q. Y., Liu, Z. J. (1991): Early five years' effect of fertilization on young Chinese fir plantation. - Chinese Journal of Soil Science 22(11): 28-32 (in Chinese with English abstract).

[24] Li, W. H., Li, F. (1996): Research of Forest Resources in China. - China Forestry Publishing House, Beijing, China, pp. 39-53 (in Chinese with English abstract).

[25] Li, J., Chen, X., Zhu, N., Tan, Y., Yan, Y., Gao, Z., Zhang, Y. (2013): Study on selection of main fuel-wood forest tree species in South China and combustion characteristics of wood pellets of fuel-wood trees. - Journal of Central South University of Forest and Technology 33: 126-129.

[26] Liao, L. P., Ma, Y. Q., Wang, S. L., Gao, H., Yu, X. J. (2000): Decomposition of leaf litter of Chinese fir in mixture with major associated broad-leaved plantation species. Acta Phytoecological Sinica 24(1): 27-33 (in Chinese with English abstract).

[27] Lin, K., Yu, X. T., Huang, B. L., He, Z. Y. (2001): Dynamical characteristics of undergrowth plant diversity in Chinese fir plantations. - Chinese Journal of Applied and Environmental Biology 7(1): 13-19 (in Chinese with English abstract).

[28] Liu, B., Liu, Q., Daryanto, S., Guo, S., Huang, Z., Wang, Z., Wang, L., Ma, X. (2018): Responses of Chinese fir and Schima superba seedlings to light gradients: Implications for the restoration of mixed broadleaf-conifer forests from Chinese fir monocultures. Forest Ecology and Management 419: 51-57.

[29] Ma, X., Liu, A., Ma, Z., Fan, S. (2000a): A comparative study on nutrient accumulation and distribution of different generations of Chinese fir plantations. - Chinese Journal of Applied Ecology 11(4): 501-506 (in Chinese with English abstract).

[30] Ma, X., Ye, S., Chen, S. (2000b): Effects of rotation on site productivity maintenance of Chinese fir plantation. - Science Silvae Sinica 36(6): 47-52 (in Chinese with English abstract).

[31] Ma, X., Liu, C., Hannu, I., Westman, C. J., Liu, A. (2002): Biomass, litterfall and the nutrient fluxes in Chinese fir stands of different age in subtropical China. - Journal of Forestry Research 13(3): 165-170.

[32] Ma, X., Heal, K., Liu, A., Jarvis, P. G. (2007): Nutrient cycling and distribution in different-aged plantations of Chinese fir in southern China. - Forest Ecology and Management 243(1): 61-74.

[33] Minghe, L., Ritchie, G. A. (1999): Eight hundred years of clonal forestry in China: I. traditional afforestation with Chinese fir (Cunninghamia lanceolata (Lamb.) Hook.). New Forests 18(2): 131-142.

[34] Paul, E. A. (2014): Soil microbiology, ecology and biochemistry. - Academic Press.

[35] Piao, S., Ciais, P., Huang, Y., Shen, Z., Peng, S., Li, J., Zhou, L., Liu, H., Ma, Y., Ding, Y., Friedlingstein, P. (2010): The impacts of climate change on water resources and agriculture in China. - Nature 467(7311): 43. 
[36] Selvaraj, S., Duraisamy, V., Huang, Z., Guo, F., Ma, X. (2017): Influence of long-term successive rotations and stand age of Chinese fir (Cunninghamia lanceolata) plantations on soil properties. - Geoderma 306: 127-134.

[37] State Forestry Administration (2014): General Situation of Forest Resources in China The $8^{\text {th }}$ National Forest Inventory. - State Forestry Administration, Beijing.

[38] Tang, X., Lu, Y., Fehrmann, L., Forrester, D. I., Guisasola-Rodríguez, R., Pérez-Cruzado, C., Kleinn, C. (2016): Estimation of stand-level aboveground biomass dynamics using tree ring analysis in a Chinese fir plantation in Shitai County, Anhui Province, China. New Forests 47(2): 319-332.

[39] Tian, D., Xiang, W., Chen, X., Yan, W., Fang, X., Kang, W., Dan, X., Peng, C., Peng, Y. (2011): A long-term evaluation of biomass production in first and second rotations of Chinese fir plantations at the same site. - Forestry 84(4): 411-418.

[40] Wang, Q. K., Wang, S. L. (2008): Soil microbial properties and nutrients in pure and mixed Chinese fir plantations. - Journal of Forestry Research 19(2): 131-135.

[41] Wang, B., Wei, W., Xing, Z., You, W., Niu, X., Ren, X., Liu, C. (2012): Biomass carbon pools of Cunninghamia lanceolata (Lamb.) Hook. forests in subtropical China: Characteristics and potential. - Scandinavian Journal of Forest Research 27(6): 545-560.

[42] Wang, L., Zhang, Y., Berninger, F., Duan, B. (2014): Net primary production of Chinese fir plantation ecosystems and its relationship to climate. - Biogeosciences Discussions 11(4). DOI: $10.5194 /$ bgd-11-5639-2014.

[43] Wenhua, L. (2004): Degradation and restoration of forest ecosystems in China. - Forest Ecology and Management 201(1): 33-41.

[44] Wood, T. E., Lawrence, D., Clark, D. A., Chadzon, R. L. (2009): Rain forest nutrient cycling and productivity in response to large-scale litter manipulation. - Ecology 90(1): 109-121.

[45] Wu, Z. L. (1984): Chinese fir. - Forestry of China Publications, Beijing.

[46] Wu, P., Ma, X., Tigabu, M., Wang, C., Liu, A., Oden, P. C. (2011): Root morphological plasticity and biomass production of two Chinese fir clones with high phosphorus efficiency under low phosphorus stress. - Canadian Journal of Forest Research 41(2): 228-234.

[47] Wu, Z., Li, J., Zheng, J., Liu, J., Liu, S., Lin, W., Wu, C. (2017): Soil microbial community structure and catabolic activity are significantly degenerated in successive rotations of Chinese fir plantations. - Scientific Reports 7(1): 6691.

[48] Xiong, H. (2008): Study on variation of the properties of soil in multi-storied Chinese fir plantation. - Subtropical Agriculture Research 4(4): 283-286 (in Chinese with English abstract).

[49] Yang, Y. S., Guo, J., Chen, G., Xie, J., Gao, R., Li, Z., Jin, Z. (2005): Carbon and nitrogen pools in Chinese fir and evergreen broadleaved forests and changes associated with felling and burning in mid-subtropical China. - Forest Ecology and Management 216(1-3): 216-226.

[50] You, C., Jiang, L., Xi, F., Wang, W., Li, M., Xu, Z., Gu, L., Wang, F., Zhang, Z. (2015): Comparative evaluation of different types of soil conditioners with respect to their ability to remediate consecutive tobacco monoculture soil. - International Journal of Agriculture and Biology 17(5). DOI: 10.17957/IJAB/15.0017.

[51] Yu, X. (1997): Silviculture of Chinese Fir. - Science and Technology Press of Fujian, Fuzhou.

[52] Zhang, X., Kirschbaum, M. U., Hou, Z., Guo, Z. (2004): Carbon stock changes in successive rotations of Chinese fir (Cunninghamia lanceolata (lamb) hook) plantations. Forest Ecology and Management 202(1-3): 131-147.

[53] Zhang, W., Lu, Z., Yang, K., Zhu, J. (2017): Impacts of conversion from secondary forests to larch plantations on the structure and function of microbial communities. Applied Soil Ecology 111: 73-83. 
[54] Zhao, M., Zhou, G.-S. (2005): Estimation of biomass and net primary productivity of major planted forests in China based on forest inventory data. - Forest Ecology and Management 207(3): 295-313.

[55] Zhao, M., Xiang, W., Tian, D., Deng, X., Huang, Z., Zhou, X., Peng, C. (2013): Effects of increased nitrogen deposition and rotation length on long-term productivity of Cunningham lanceolata in Southern China. - PLoS One 8(2): 55376.

[56] Zhijun, H., Selvalakshmi, S., Vasu, D., Liu, Q., Cheng, H., Guo, F., Ma, X. (2018): Identification of indicators for evaluating and monitoring the effects of Chinese fir monoculture plantations on soil quality. - Ecological Indicators 93: 547-554.

[57] Zhou, L., Addo-Danso, S. D., Wu, P., Li, S., Ma, X. (2015): Litterfall production and nutrient return in different-aged Chinese (Cunningham lanceolata) plantations in South China. - Journal of Forestry Research 26(1): 79-89.

[58] Zhou, H., Meng, S., Liu, Q. (2016a): Diameter Growth, Biological Rotation Age and Biomass of Chinese Fir in Burning and Clearing Site Preparations in Subtropical China. Forests 7(8): 177.

[59] Zhou, L., Cai, L., He, Z., Wang, R., Wu, P., Ma, X. (2016b): Thinning increases understory diversity and biomass, and improves soil properties without decreasing growth of Chinese fir in southern China. - Environmental Science and Pollution Research 23(23): 24135-24150.

[60] Zhou, L., Shalom, A. D. D., Wu, P., He, Z., Liu, C., Ma, X. (2016c): Biomass production, nutrient cycling and distribution in age-sequence Chinese fir (Cunninghamia lanceolate) plantations in subtropical China. - Journal of Forestry Research 27(2): 357-368. 